\title{
SWAMI, Stored Waste Autonomous Mobile Inspector
}

by

K. McCarthy

Westinghouse Savannah River Company

Savannah River Site

Aiken, South Carolina 29808

M. R. Duignan

A document prepared for KOREA ATMONIC ENERGY RESEARCH INSTITUTE at Yusong, Taejon from 07/16/95 07/22/95.

DOE Contract No. DE-AC09-89SR18035

This paper was prepared in connection with work done under the above contract number with the U.S.

Department of Energy. By acceptance of this paper, the publisher and/or recipient acknowledges the U.S. Government's right to retain a nonexclusive, royalty-free license in and to any copyright covering this paper, along with the right to reproduce and to authorize others to reproduce all or part of the copyrighted paper. 


\section{DISCLAIMER}

Portions of this document may be illegible in electronic image products. Images are produced from the best available original document. 


\section{DISCLAIMER}

This report was prepared as an account of work sponsored by an agency of the United States Government. Neither the United States Government nor any agency thereof, nor any of their employees, makes any warranty, express or implied, or assumes any legal liability or responsibility for the accuracy, completeness, or usefulness of any information, apparatus, product, or process disclosed, or represents that its use would not infringe privately owned rights. Reference herein to any specific commercial product, process, or service by trade name, trademark, manufacturer, or otherwise does not necessarily constitute or imply its endorsement, recommendation, or favoring by the United States Government or any agency thereof. The views and opinions of authors expressed herein do not necessarily state or reflect those of the United. States Government or any agency thereof.

This report has been reproduced directly from the best available copy.

Available to DOE and DOE contractors from the Office of Scientific and Technical Information. P. O. Box 62, Oak Ridge, TN 37831; prices available from (615) $576-8401$.

Available to the public from the National Technical Information Service, U. S. Department of Commerce, 5285 Port Royal Rd., Springfield, VA 22161 


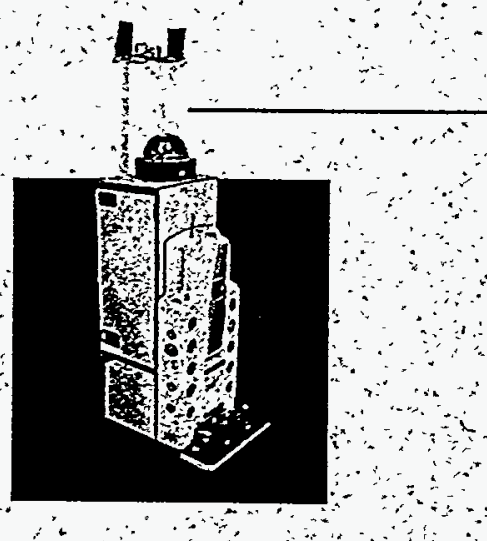

SWAMI, Stored

Waste Autonomous MobileInspector

\section{Technology Brief}

\section{Highlights}

Savannah River Technology Centerhavie developeda robotics śsystem called" SWAMI, the Stored Waste Autonómoús Mobile Inspector.

The system improves the inspection and inventory of: drüms containing low-level radioactive, hazardous and mixed wastes, while greatly; reducing personnel expo: sure to hazardous mateijals.

SWAMI is a modified version of the HelpMate robót produced by:Transitions Research Corporátion, of Danbury, Conn.

Additions to the robot include off-board control and display, on-board control,'radioethemet communications, image recording, image compression, image
口. Scientists at the

\section{Robot makes drum inspection safer and more efficient}

A mobile robot named SWAMl, developed by scientists at the Savannah River-Technology Center is making the tedious and potentially dangerous job of drum inspection safer and more efficient.

Department of Energy sites store tens of thousands of drums containing low-level radioactive, hazardous and mixed wastes around the country Regulations reguire weekly inspection of these drums a monotônous, time consuming taskworkers perform in hostile environments.

\section{Reduces personnel exposure}

The robotics system improves the efficiency, documentation andaccuracy of drum inspections and inventon, while greatly reducing personne fexposure to hazardous materials Also tests show that a mobile robot can detectfloor contamination more reliably and accurately than tedious manual surveys

With decommissioning of closed nuclear facilities expected to generate more waste robotic systems will play a crucial role in futurie waste inspection and inventory

SWANiperforms snspections autonomously afteran inspector operating the host computer sends the roboton its way The robot capturesan image of êch drum and reads the barcodes storing the data it gatthers on an on-board computer SWAMI also transmits databack to the host computer to allow operators to monitor the vehicle's location, condition and other relevant information in real time After the inspection drum imàges áre studied to detect any suspect containers, and inventories are ùpdăted with bar=codè data

\section{Radiation survey}

of Ênergy

Additional information is ávailable from:

Westinghouse Savanah River Company 227 Gateway Drive Aiken, $S \mathrm{C} 29803$

Tel. [800] 228-3843

Fax $[803] 652-1898$

The robot also conducts a radiation survey of the floor during each inspection if high contamination is found, it stops and notifies appropriate personnel. Data is ùsed to generate radiation maps of both alpha and beta/gamma levels in facility aisles. 6 . SWAM is a modified version of the HelpMate robot produced by Transitions Besearch Corporation of Danbury, Conn Until now, the HelpMate has been used for hospital applications such as mealdeliven to patients: Technology Centeradditions to this robot include off-board control and display, on-board control, radio ethernet communications, image recording barcode reading, radiation survey and radiation data display.

The on-board control system, developed by the University of South Carolina, supervises all of SWAMI's subsystems and conforms to the Generic intelligent System Controi This 


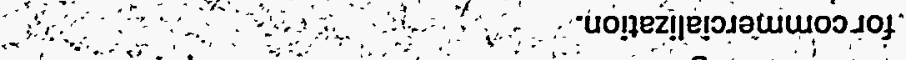

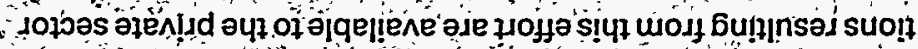

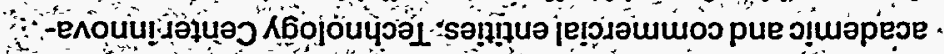

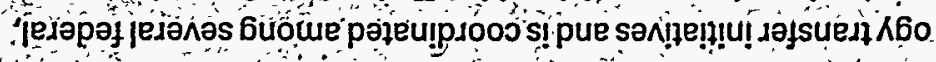

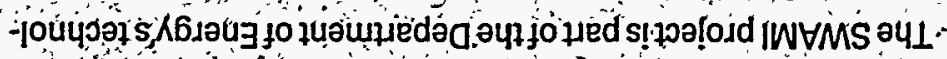

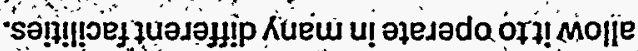

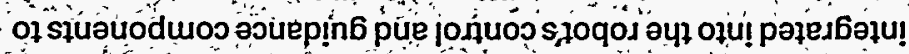

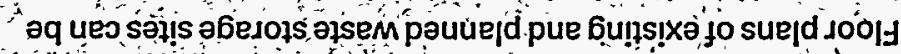

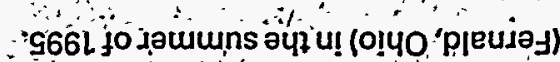

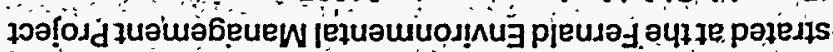
-uoüp әq il!

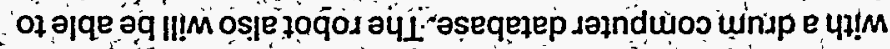

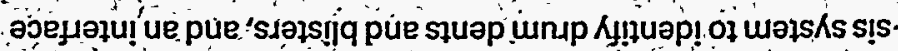

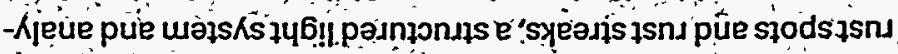

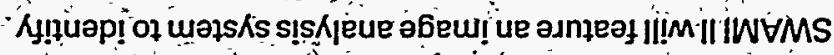

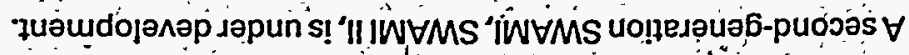

'IIIN⿴囗MS 6uịnponu!

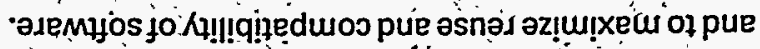

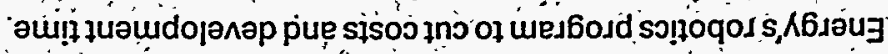

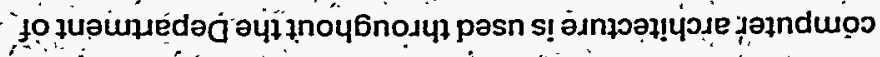

